*alls View/Frint Document Cover Sheet tose

This document was retrieved from the Boeing ISEARCH System.

Accession \#: D196054919

Document \#: SD-WM-TRP-245

Title/Desc:

183H SLUDGE TREATABILITY TEST REPORT 


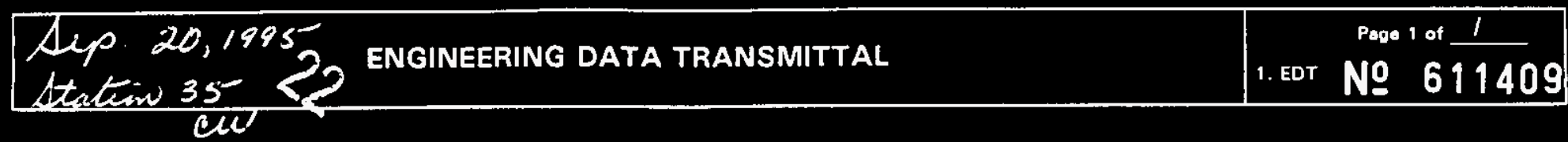

\begin{tabular}{|c|c|c|}
\hline $\begin{array}{l}\text { 2. To: (Receiving organization) } \\
\text { Generator/Waste Acceptance } \\
\text { Services }\end{array}$ & $\begin{array}{l}\text { 3. Fron: (originating organization) } \\
\text { Engineered Process } \\
\text { Applications }\end{array}$ & $\begin{array}{l}\text { 4. Related EDT No.: } \\
\text { NA }\end{array}$ \\
\hline $\begin{array}{l}\text { 5. Proj./Prog./Dept./Div.: } \\
\text { Solid Waste Disposal }\end{array}$ & $\begin{array}{l}\text { 6. Cog. Engr.: } \\
\text { R. K. Biyani }\end{array}$ & $\begin{array}{c}\text { 7. Purchase Order No.: } \\
\text { NA }\end{array}$ \\
\hline \multirow{2}{*}{\multicolumn{2}{|c|}{$\begin{array}{l}\text { 8. Originator Remarks: } \\
\text { Approval/Issuance of "183-H Bas in Sludge Treatability Test } \\
\text { Report" is requested }\end{array}$}} & $\begin{array}{l}\text { 9. Equip./Component No.: } \\
\text { NA }\end{array}$ \\
\hline & & $\begin{array}{r}\text { 10. System/Bldg./Facility: } \\
\text { B1dg. } 377 \\
\end{array}$ \\
\hline \multirow{3}{*}{\multicolumn{2}{|c|}{ 11. Receiver Remarks: }} & $\begin{array}{l}\text { 12. Major Assm. Dwg. No.: } \\
\text { NA }\end{array}$ \\
\hline & & $\begin{array}{l}\text { 13. Permit/Permit Application No.: } \\
\text { NA }\end{array}$ \\
\hline & & $\begin{array}{l}\text { 14. Required Response Date: } \\
9 / 15 / 95\end{array}$ \\
\hline
\end{tabular}

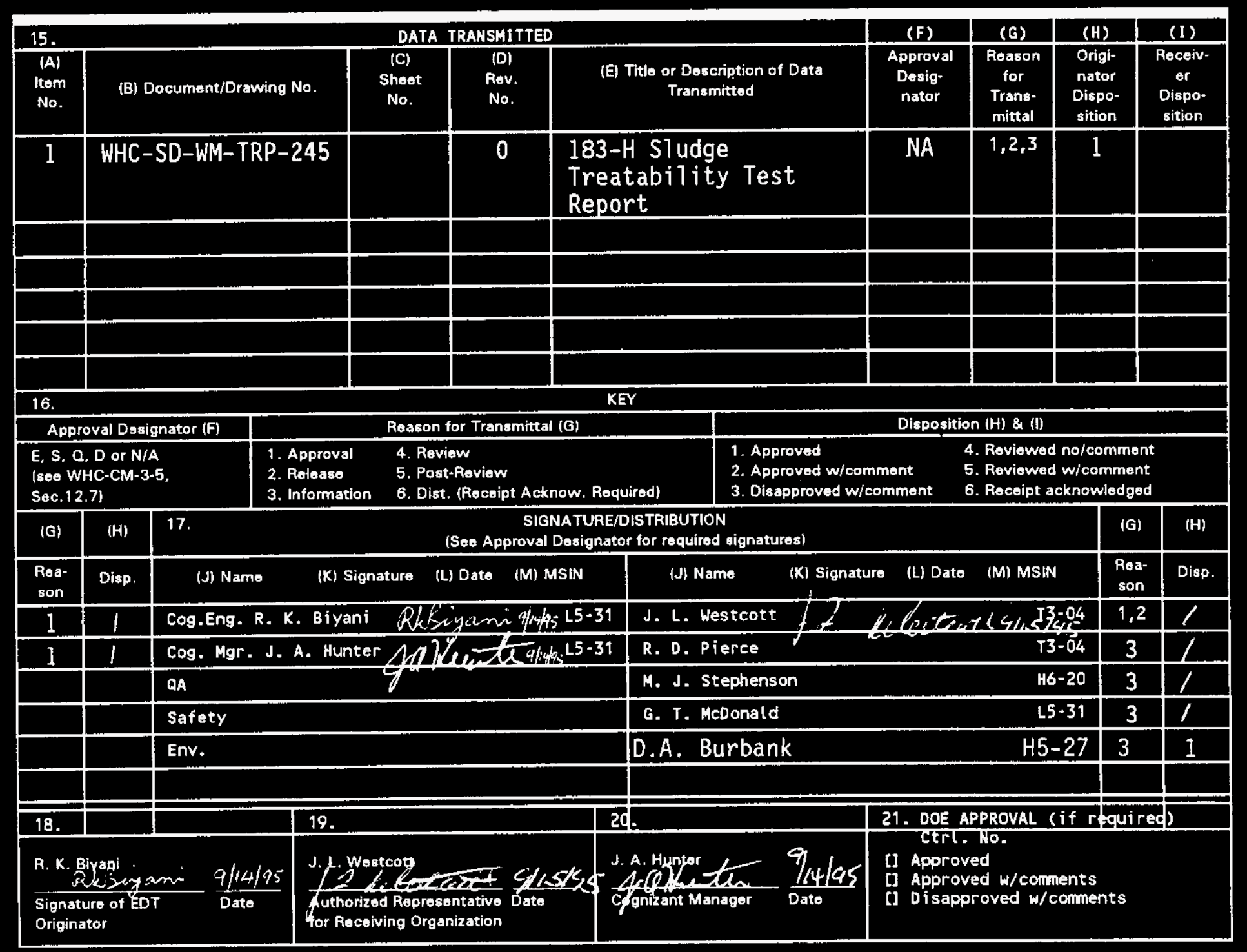




\section{RELEASE AUTHORIZATION}

Document Number: $\quad$ WHC-SO-WM-TRP-245, Rev. 0

Document Title: $\quad 183-\mathrm{H}$ Basin Sludge Treatability Test Report

Release Date: $\quad 9 / 18 / 95$

This document was reviewed following the procedures described in WHC-CM-3-4 and is:

APPROVED FOR PUBLIC RELEASE

WHC Information Release Administration Specialist:

Chis stilling gham

C. WILLINGHAM
$9 / 18 / 95$

TRADEMARK DISCLAIMER. Reference herein to any specific commercial product, process, or service by trade name, trademark, manufacturer, or otherwise, does not necessarily constitute or imply its endorsement, recommendation, or favoring by the United States Government or any agency thereof or its contractors or subcontractors.

This report has been reproduced from the best available copy. Available in paper copy. Printed in the United States of America. To obtain copies of this report, contact:

West inghouse Hanford Company - Document Control Services

P.O. Box 1970, Mailstop H6-08, Richland, WA 99352

Telephone: (509) 372-2420; Fax: (509) 376-4989 
2. Title

3. Number WHC-SD-WM-TRP-245

183-H Basin Sludge Treatability Test Report

5. Key Words

Treatability, Cementitious, 183-H Basin, Sludge, Test
6. Author

Name: R. K. Biyani

Rl/Siyani

Organization/Charge Code

7. Abstract

This document presents the results from the treatability testing of a $1-\mathrm{kg}$ sample of 183-H Basin sludge. Compressive strength measurements, Toxic Characteristic Leach Procedure, and a modified ANSI 16.1 leach test were conducted.

8.

RELEASE STAMP

4. Rev No. 0 
WHC-SD-WP-TRP-245 Rev.0

\title{
183-H BASIN SLUDGE \\ TREATABILITY TEST REPORT
}

\author{
R. K. Biyani \\ Westinghouse Hanford Company \\ September 1995
}


WHC-SD-WM-TRP-245 Rev. 0

CONTENTS

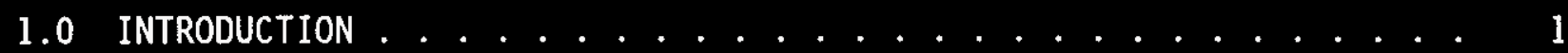

2.0 PREPARATION Of SAMPLES ................ 1

3.0 DEMONSTRATION OF TREATMENT TECHNOLOGY .............. 2

4.0 WASTE FORM PERFORMANCE ....................... 2

4.1 Density \& Compressive Strength Measurement . . . . . . . . 2

4.2 Toxicity Characteristic Leach Procedure (TCLP) Test . . . . 3

4.3 90-day Water Immersion Test . . . . . . . . . . . 4

4.4 Modified ANSI 16.1 Test .............. 4

5.0 CONCLUSIONS ....................... 5

6.0 REFERENCES ....................... 5

7.0 ACKNOWLEDGEMENT $\ldots \ldots \ldots \ldots$

\section{TABLES}

Table 1. Containers Used for the Preparation of Cementitious Specimens . 1

Table 2. Penetrometer Test Results .............. 2

Table 3. Waste Form Performance Criteria. . . . . . . . . . . 2.

Table 4. Density \& Compressive Strength Results ........... 3

Table 5. TCLP Results ................ 3 
WHC-SD-WM-TRP-245, Rev. 0

\subsection{INTRODUCTION}

183-H Basins contained residual sludges from the solar evaporation of miscellaneous wastes from fuel fabrication in the 300 Area. These mixed wastes have been retrieved and are now stored in 208L (55-gal) drums in the Central Waste Complex. A $1-\mathrm{kg}$ sample of sludge from Basin 4 was evaluated fór immobilization of radionuclides and hazardous constituents in a cementitious matrix. This treatability study is the subject of this report. The governing documents for the preparation and testing of samples are Burbank (1994) and Biyani (1994): Sample preparation and waste form performance testing were done in Building 377. Chemical and radiological analys is of leachate, basin sludge, and grout samples was done in the 222-S Lab.

\subsection{PREPARATION OF SAMPLES}

Several 208L (55 gal) drums from 183-H Basins were sampled in Building 377 . A tube sampling method was used to retrieve 4 cores, one from each quadrant. The tubes used were $75 \mathrm{~cm}$ long, reaching to within a few inches of the bottom of the drum, thereby giving a full profile of the contents in the drum. Approximately $15 \mathrm{~L}$ of sludge was withdrawn from each drum, transferred to a bowl, and mixed we11. This composited sample was then transferred to several $2 \mathrm{~L}$ containers.

A 1-kg sample of Basin 4 sludge, taken as above from drum PIN \# 183-H4-0000736, was used for this study. This sludge sample was found to contain about $45 \mathrm{wt} \%$ of gravelly material. The gravelly material was probably from the pozzolan added to the top of drums to absorb any free liquids present when the 183-H basin waste was packaged. This pozzolan and free liquid mixture subsequently solidified as a hard layer which fragmented when the drums were being sampled.

The entire sludge sample was transferred to a laboratory blender. The pieces of pozzolan, $\mathbf{~}^{\prime \prime}$ - $1^{\prime \prime}$ in diameter, had to be temporarily separated from the sludge to allow free rotation of the mixer blades. Portland cement Type I-II, fly ash, and water were added in amounts equal to the sludge weight and mixed to form a uniform slurry. After completion of mixing, the grit which was removed from the sludge was blended back into the mixture with a spatula. The presence of the grit precluded use of a viscometer for measuring the slurry viscosity. The slurry was easily pourable into eleven sample molds of different sizes described in the test procedures (Biyani, 1994) and listed in Table 1 . All samples were cured in air tight jars at room temperature $\left(21^{\circ} \mathrm{C}\right)$.

Table 1. Containers Used for the Preparation of Cementitious Specimens

\begin{tabular}{|c|c|c|c|c|}
\hline Sample No. & Quantity & $\begin{array}{c}\text { Volume } \\
(\mathrm{ML})\end{array}$ & $\begin{array}{c}\text { Dimensions } \\
\text { Diam. X Length }\end{array}$ & Purpose \\
\hline $1,2,3$ & 3 & 206 & $50 \mathrm{~mm} \times 100 \mathrm{~mm}$ & As cured Comp. Strength. \\
\hline $4,5,6$ & 3 & 206 & $50 \mathrm{~mm} \times 100 \mathrm{~mm}$ & $\begin{array}{c}\text { Comp. Strength after } \\
90 \text {-Day Immers ion }\end{array}$ \\
\hline 7,8 & 2 & 30 & $25 \mathrm{~mm} \times 60 \mathrm{~mm}$ & Modified ANS I 16.1 Leach \\
\hline $9,10,11$ & 3 & 500 & $88 \mathrm{~mm} \times 75 \mathrm{~mm}$ & Penetrometer \\
\hline
\end{tabular}




\subsection{DEMONSTRATION OF TREATMENT TECHNOLOGY}

The initial set (solidification) of the samples, prepared as described in Section 2.0, was determined by penetrometer measurements. The goal as defined in Burbank (1994) is a minimum reading of $345 \mathrm{kPa}$ (50psi) in 48 hours. Results of penetrometer tests after 24 , and 48 hours are given in Table 2 . Another criterion of proper set was $<0.5$ wt\% free water at the end of 48 hours. The penetrometer sample inspected after 48 hours met this requirement as no free liquid was observed. The remaining samples, allowed to cure in sealed containers at room temperature for 28 days, also had no free liquids.

Table 2. Penetrometer Test Results

\begin{tabular}{|c|c|c|c|}
\hline Sample \# & $\begin{array}{c}\text { Curing Time, } \\
\text { hours }\end{array}$ & Penetrometer Type & $\begin{array}{c}\text { Penetrometer Reading, } \\
\text { xPA }\end{array}$ \\
\hline \hline 9 & 24 & Handheld & $2620(380$ psi) \\
\hline 10 & 48 & Benchtop & $>5520(800 \mathrm{psi})$ \\
\hline
\end{tabular}

\subsection{WASTE FORM PERFORMANCE}

Minimum acceptable criteria for samples, after allowing 28-day cure time, are presented in Table 3.

Table 3. Waste Form Performance Criteria

\begin{tabular}{|c|c|c|}
\hline Type of TEST & TEST Method & PASsing CRIterIA \\
\hline TCLP & $\begin{array}{c}\text { Method 1311 of 40 CFR } \\
\text { Ch.1, Pt.261, Appendix II }\end{array}$ & $\begin{array}{c}\text { Toxic Characteristics } \\
\text { List } \\
\text { WAC-173-303-090(8)(c) }\end{array}$ \\
\hline $\begin{array}{c}\text { Unconfined } \\
\text { compresssive } \\
\text { strength (UCS) }\end{array}$ & ASTM Method C39 & $3.45 \mathrm{MPa}$ (500 psi) \\
\hline $\begin{array}{c}\text { UCS following } \\
\text { 90-day water } \\
\text { immersion }\end{array}$ & ASTM Method C39 & $3.45 \mathrm{MPa}$ (500 psi) \\
\hline $\begin{array}{c}\text { Leachability } \\
\text { Index }\end{array}$ & ANS/ANSI 16.1 \\
(modified) & greater than 6.0 \\
\hline
\end{tabular}

\subsection{Density \& Compressive Strength Measurement}

Measurement of waste form density and compressive strength, after 28-day cure was done on Samples \#1, 2, and 3. Sample dimensions and weight were measured after retrieval from the mold. The samples were then capped on both ends with a molten 


\section{WHC-SD-WM-TRP-245, Rev. 0}

sulfur capping compound and tested for compressive strength. Results are presented in Table 4.

Table 4. Density \& Compressive Strength Results

\begin{tabular}{|c|c|c|}
\hline SAMPLE \# & BuLK Density (G/ML) & Compressive StrengtH MPA \\
\hline 1 & 1.79 & $7.76(1125 \mathrm{psi})$ \\
\hline 2 & 1.84 & $9.57(1388 \mathrm{psi})$ \\
\hline 3 & 1.81 & $7.18(1041 \mathrm{psi})$ \\
\hline Average & 1.81 & $8.17(1185 \mathrm{psi})$ \\
\hline
\end{tabular}

\subsection{Toxicity Characteristic Leach Procedure (TCLP) Test}

The TCLP test was performed on Samples \# 1 \& 2 using the method specifed in Table 3. The samples were first tested for compressive strength, and then fragments obtained thereof were used for the TCLP test.

Sludge analysis obtained from Weston Labs was used to calculate the theoretical upper limit of contaminant concentrations possible in the leachate obtained by a TCLP test (assuming all contaminants leached out completely). Both sets of figures are reported in the Table 5 .

Table 5. TCLP Results

\begin{tabular}{|c|c|c|c|c|}
\hline \multirow[t]{2}{*}{ CONTAMINANT } & \multirow{2}{*}{$\begin{array}{c}\text { Maximum Allowable } \\
\text { Leachate Conc by WAC } \\
\text { CRIteria (see Table 3) } \\
\text { Mg/KG }\end{array}$} & \multirow{2}{*}{$\begin{array}{c}\text { UPPER LIMIT OF } \\
\text { CONTAMINANT CONC } \\
\text { THEORETICALLY POSSIBLE } \\
\text { MG/KG }\end{array}$} & \multicolumn{2}{|c|}{$\begin{array}{c}\text { CONTAMINANT CONC OBTAINED BY } \\
\text { LEACHATE ANALYSIS } \\
\text { MG } / \mathrm{KG}\end{array}$} \\
\hline & & & Sample \# 1 & Sample \#2 \\
\hline Barium & 100 & 0.06 & $<0.5$ & $<0.5$ \\
\hline Cadmium & 1 & 0.04 & $<0.1$ & $<0.1$ \\
\hline Chromium & 5 & 2.05 & 0.40 & 0.39 \\
\hline Mercury & 0.2 & 0.09 & $<0.03$ & $<0.03$ \\
\hline Selenium & 1 & 0.004 & not analyzed & not analyzed \\
\hline Silver & 5 & 0.23 & $<0.1$ & $<0.1$ \\
\hline
\end{tabular}




\subsection{0-day Water Immersion Test}

Samples \#4, 5, and 6 were tested per the 90-day water immersion test required in Biyani (1994). At the end of the test period, the samples were structurally sound without any visible disintegration. At the end of the test, the $\mathrm{pH}$ of the water used for immersion was 13.2 .

The compressive strength of the samples was measured after capping both ends with sulfur capping compound. The strengths were $8.7,7.2$, and $12.7 \mathrm{MPa}$. The average compressive strength of the samples was $9.55 \mathrm{MPa}$ (1385 psi). A11 samples passed the compressive strength test requirement.

\subsection{Modified ANSI 16.1 Test}

The ANSI/ANS-16.1 leach test and the interpretation and application of the Leachability Index is described in ANS (1986). For this treatability test the water sampling/changeout time intervals have been slightly changed from the above standard -- thus the use of the word 'modified' in the heading. The reason for this was to allow all work to be completed during normal working hours. The total number of leachate samples taken in the modified test is 9 whereas in the ANSI 16.1 standard it is 11. However, since the total leaching time for both methods is 90 days, the test results are expected to be very similar.

The water sampling schedule used for this test is described in Biyani (1994) and is commonly used by other laboratories at the Hanford site. Leachate samples were analyzed for nitrate, uranium, and technetium-99 and results are presented in Table 6.

The ANSI 16.1 standard evaluates the diffusivity of a specific analyte from within a waste form during fixed intervals of time. The Leachability Index is defined as the log of the reciprocal of the diffusivity and is averaged over the specified time intervals for each species. The Leachability Index has been specified to be above 6.0 for waste form acceptance (Burbank (1994) and NRC (1991)). Although it is a parameter which is limited to the specified formulation for which it was determined, the Leachability Index can be used to predict the loss of waste comoponents from a waste form of any size and shape.

Table 6. Leachability Test Results

\begin{tabular}{|c|c|c|c|}
\hline \multirow{2}{*}{ Constituent } & \multicolumn{3}{|c|}{ Leachability Index } \\
\cline { 2 - 4 } & Sample \#7 & Sample \# 8 & Average \\
\hline \hline Nitrate & 8.0 & 8.1 & 8.1 \\
\hline Uranium (gross) & 14.9 & 14.4 & 14.7 \\
\hline Technetium-99 & 14.1 & 13.2 & 13.7 \\
\hline
\end{tabular}


WHC-SD-WH-TRP-245, Rev. 0

\subsection{CONCLUSIONS}

Considerable surrogate waste solidification and testing has been performed on 183-H Basin sludge (Duchsherer, 1994). Experience from those tests was used to specify a formulation for use in this study. These tests, with actual waste, yielded results similar to previous surrogate waste stabilization and performance testing.

By this study, solidification of 183-H Basin sludge using cementitious binders has been successfully demonstrated. Proper curing without gas generation or excessive heat evolution has confirmed successful application of this treatment technology. All samples tested passed acceptance criteria given in Table 3 .

This test is a positive beginning in the treatment of the large inventory of 183-H Basin sludge which has been divided into seven major categories. Treatability testing reveals problems which are not discernible with surrogate tests, e.g. the presence of gravelly material in the sludge which will require careful mixer design for a larger scale operation.

Treatability testing of the remaining six categories of $183-\mathrm{H}$ Bas in waste also needs to be done. Future testing should include parametric studies to develop tailored cement matrices for maximizing waste loading. Such optimization will yield minimum waste form volume.

\subsection{REFERENCES}

ANS, 1986, American National Standard Measurement of the Leachability of Solidified Low-Level Radioactive Wastes by a Short-Term Test Procedure, Prepared by ANS Standards Committee Working Group ANS-16.1, La Grange Park, I11 inois.

ASTM, 1994, Standard Test Method for Compressive Strength of Cylindrical Concrete Specimens, C39, Prepared by Subcommittee C09.61 on Testing Concrete for Strength, American Society for Testing and Materials, Philadelphia, Pennsylvania.

Biyani, R. K., 1994, Test Procedures for WRAP 2A Treatability Study, WHC-SD-W100TC -001 Rev. 0, Westinghouse Hanford Company, Richland, Washington.

Burbank, D. A., 1994, 183-H Basin Sludge Treatability Testing Program P7an, WHC-SD-W1O0-AP-002 Rev. 1, Westinghouse Hanford Company, Richland, Washington.

Duchsherer, M. J., 1994, CEL Working Procedures for WRAP 2A Formulation Development Tests, WHC-SD-W100-TP-011, Westinghouse Hanford Company, Richland, Washington.

NRC, 1991, Technical Position on Waste Form (Rev. 1), Prepared by Technical Branch, Division of Low-Level Waste Management and Decommissioning, Nuclear Regulatory Commission, Washington, DC. 
WHC-SD-WH-TRP-245, Rev. 0

\subsection{ACKNOWLEDGEMENT}

The author would like to acknowledge the contributions made by George T. McDonald in the development of lab data presented in this report. 